\title{
ENERGY EFFICIENT POWER SUPPLY SYSTEMS OF OIL AND GAS PIPELINES ELECTRIC DRIVES
}

\author{
O.V. Kryukov ${ }^{1}$, o.kryukov@ggc.nnov.ru \\ A.V. Serebryakov ${ }^{2}$ \\ ${ }^{1}$ JSC "Giprogazcenter", Nizhny Novgorod, Russian Federation, \\ ${ }^{2}$ Nizhny Novgorod State Technical University n.a. R.E. Alekseev, \\ Nizhny Novgorod, Russian Federation
}

\begin{abstract}
The current state of development of autonomous power supply systems is considered including the facilities of gas-transport systems. The use of electric power alternative sources on the base of wind plants in the combined generating complexes is substantiated. The options of electric networks structures with the use of wind plants are suggested for along-the-route consumers. Power effective invariant systems on the basis of combined units under the scheme "synchronous generator - frequency converter" are analyzed. The authors received the predicted amount of generated electric power by power suppliers at wind stream stochastic nature. A number of examples of introduction of the new combined systems of autonomous power supply using renewable power sources in the main gas pipelines of the Russian Federation are given.
\end{abstract}

Keywords: wind plant, invariant system, power efficiency, synchronous generator, frequency converter.

\section{Introduction}

The geographical position of the Russian Federation preconditions the availability of large territories (approximately $2 / 3$ ) with a low population density (not more than 20 million persons) that assumes the necessity of their autonomous power supply. As autonomous power sources (APS), basically, diesel power stations and boiler units on coal, masout or other imported fuel are used here. However, these means become today more and more money-losing and environment-unfriendly [1-4].

On the other hand, there is a great experience in power engineering of our country and worldwide of creating and using modern renewable energy sources (RES) as an alternative or in a combination with hydrocarbon ones [5-8]. For example, a total capacity of wind plants (WP) in the world has reached $194 \mathrm{GW}$ with up to 0.593 efficiency and more than $430 \mathrm{TW} \cdot \mathrm{h}$ output [8-11].

Innovative research on improving renewable and combined APS have not lost their urgency nowadays [10-13]. Moreover, the new hardware base of electromechanical engineering, power electronics and microprocessor technics additionally stimulates the developers to create hi-tech, power effective, reliable and quickly paid back units and systems [13-18]. It is especially actual for power supply systems (PSS) of along-the-route consumers of the gas-transport systems of Russia where requirements on APS reliability, ecological compatibility and power efficiency provision $[19,20]$ are high.

Despite the large history of PSS designing and creation on WP basis and availability of state normative documents, insufficient attention is paid to study on improvement of power efficiency, stability, ecological compatibility and reliability of their work. Stan dard solutions of PSS with WP implement only certain tasks without providing a complex of problems of creation of competitive intelligent power supply sources (IPSS) on the basis of the principles of activeadaptive "smart" electric grids $[8,13,21]$. The recently approved $[1,2]$ regulations of the Russian Federation stimulate the search of innovative power saving technologies of PSS on the WP basis for objects and consumers of various industries (agricultural, prospecting, gas-transport and so forth).

At present, a part of RES in Russia constitutes $0.6-0.8 \%$ of the volume of internal power consumption while in the industrially advanced countries it reaches 5-30\%. At the same time, annual windenergetic potential of Russia at wind speed of 5-7 m/s 2,000 times exceeds its today's production volume. In separate areas where power supply problems are difficult to be solved: the Far North, oceans coasts, back-country districts etc. and these regions are characterized by low power load density, a considerable quantity of small and allocated consumers (including gas production and transport objects) which connection to the central networks is unprofitable, APS application is reasonable, allowing to save fuel and to improve ecological conditions.

The listed factors play a key role in decision making on the development of alternative PSS APS of along-the-route consumers (ARC) [11-13]. Their improvement is gathering a rapid pace now emphasizing ecological compatibility and a quick payback. Besides, the anticipated natural gas price increase is the factor in favor of developing generating capacities on the APS basis. Under these conditions the expediency of natural gas use as fuel essentially decreases even for the objects of gas-transport enterprises, ARC in particular. 
I. PSS requrements analysis of main gas pipelines along-the-route consumers

The main linear consumers (ARC) of electric power are [20]:

- electrochemical protection units (ECP),

- linear telemechanics controlled stations (LT CS),

- radio relay (RRL) communication equipment,

- gas metering stations (GMS),

- pig launching (receiving) stations (PLS, PRS),

- gas distribution stations (points) (GDS, GDP),

- gas reduction unit (GRU),

- operator's house, pipeline worker house $(\mathrm{OH}$, PWH),

- helipads (HP) and others.

The technical characteristics of the main ARC are represented in the Table 1.

A total power of these consumers reaches, according to various gas transport companies, from 0.25 to $9 \mathrm{MW}$, and the length of the along-the-route PL makes $150-4,800 \mathrm{~km}$. Such a vast parameters range assumes an individual adaptive approach to forming the sources and APS scheme under PSS designing of each section.

The structure formation of modern ARC PSS is determined by their specific features, and a considerable extent of gas pipelines and ARC dispersion remoteness of objects from external power sources and central networks as well as small electric demands of linear consumers $(2-40 \mathrm{~kW})$ are the crucial ones.

\section{ARC PSS principles}

The reliability of linear consumers PSS is the main factor providing a stable and accident-free state of gas transport systems. Modern PSS of linear consumers are being designed in accordance with three basic variants.
Variant 1 . Centralized power supply from alongthe-route overhead line OL-6 (10) kV, energized from switchgears of compressor stations or distribution networks of SS 110/10;35/10 kV. The categorization requirement is provided by the installation in a line of the automated partitioning points and ATS points. The given schemes differ by relative reliability, remote control possibility, flexibility of control algorithm, service life up to 50 years but have an essential drawback which is a high cost of the construction and connection of PL. Fig. 1 presents a standard block diagram of electrical supply of gas pipelines linear consumers.

Variant 2. A combined power supply system with external sources supply (MRSK networks) in area of ARC location, with the installation of step-down transformer substation (TS) $6(10) / 0.4 \mathrm{kV}$. PSS reliability categorization requirements are provided by installing APS at the site (DPS, "ORMAT" energy converter, hydrogen fuel cell, microturbine).

Today combined PSS represent the most preferable option for linear consumers since they possess a sufficient reliability and flexibility ensuring the work of all the installations irrespective to fuel gas availability and keeping an optimum extent of feeding OL-6 (10) kV.

Variant 3. Completely autonomous systems are applied at ARC location where OL-6 (10) kV are absent, for example, the ORMAT energy converter is the main feed power and diesel power station while the hydrogen fuel cell and other sources may provide stand-by power supply.

The independent (autonomous) electrical supply with self-contained source of supply, based on fuel gas, demands essentially less capital costs but has a direct dependence on fuel gas availability and the necessity to monitor equipment condition and operating modes, the autonomous sources nowadays are of a high cost.

Technical characteristics of main ARC

Table 1

\begin{tabular}{|l|c|c|c|c|}
\hline \multicolumn{1}{|c|}{ ARC name } & $\begin{array}{c}\text { PSS reliability category } \\
\text { according to STO } \\
\text { Gazprom 2-6.2-149-07 }\end{array}$ & $\begin{array}{c}\text { Average power, } \\
\mathrm{kW}\end{array}$ & Primary power supply & $\begin{array}{c}\text { Standby power } \\
\text { supply }\end{array}$ \\
\hline ECP units & 2 & 7 & $\begin{array}{c}\text { OL (overhead line)- } \\
(6) 10 \mathrm{kV}\end{array}$ & OL-(6)10kV, APS \\
\hline LT CS & 1 & 5 & OL-(6)10kV & APS \\
\hline $\begin{array}{l}\text { RRL communi- } \\
\text { cation }\end{array}$ & 1 & 5 & OL-(6)10kV & APS \\
\hline GMS & 1 & 20 & OL-(6)10kV & OL-(6)10kV, APS \\
\hline PLS & 3 & 2 & $\begin{array}{c}\text { OL-(6)10kV } \\
\text { of APS }\end{array}$ & - \\
\hline PRS & 1 & 2 & OL-(6)10kV & OL-(6)10kV, APS \\
\hline GDS, GDP & 3 & 15 & OL-(6)10kV & - \\
\hline GRU & 3 & 10 & OL-(6)10kV & - \\
\hline OH, PWH & 3 & 3 & OL-(6)10kV & APS \\
\hline HP & 2 & & & \\
\hline
\end{tabular}




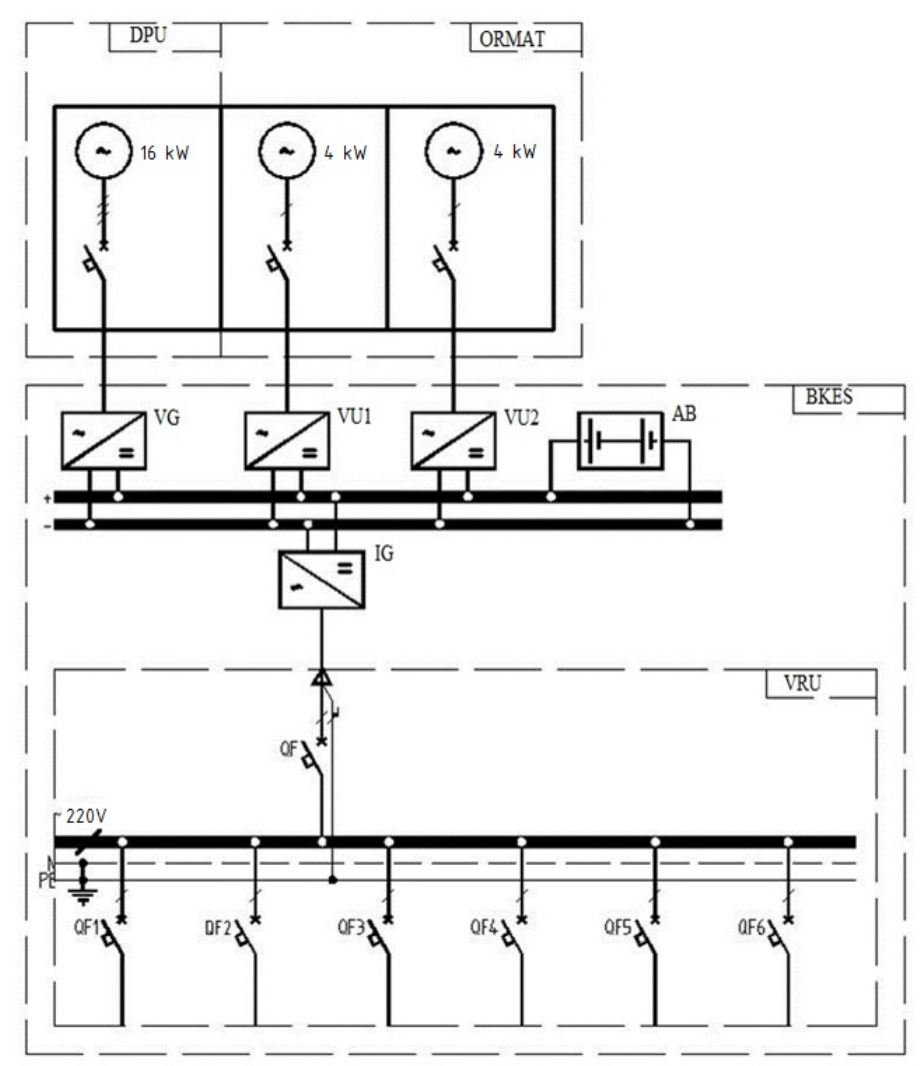

Fig. 1. ARC PSS scheme based on modular containerized power plant with APS

\section{Examples of WP construction} at along-the-route objects

In terms of the stochastic nature of amplitudefrequency characteristics of wind flow under the Weibull - Gudrich law of wind speeds distribution, the amount and quality of WP energy generation are influenced by a reasonable choice of parameters of a synchronous generator $(\mathrm{SG})\left(P_{\text {unit }}, \omega_{0}\right)$ and wind turbine operation at the optimum points of corresponding ranges of wind speeds.

Thus, under the conditions of 115 meteorological stations of the Russian Federation $[8,13]$, the calculation of basic wind power characteristics (mean annual speed of wind $V_{0}$, specific gross power $N_{\text {spec }}$, coefficient of variation $C_{v}$ ) has demonstrated that the range of their variations is wide enough and constitutes: $V_{0}=1.39 \div 7.48 \mathrm{~m} / \mathrm{s} ; \quad N_{\text {spec }}=0.01 \div 0.565 \mathrm{~kW} / \mathrm{m}^{2}$. At this, a WP with a windwheel variable frequency of rotation has a potential possibility to transform wind power into electric one with a large utilization factor of wind power even at low speeds.

To gain the maximum power efficiency modes of the WP operation in local PSS under the conditions of random wind flow and consumption, it is necessary to ensure automatic WP functioning in optimum areas by means of the APS electromechanical part.

The greatest influence on the process of WP electric power generation is exerted by the values of stochastic parameters having the meteorological (climatic) and technological nature:
- the value of wind linear speed $V, \mathrm{~m} / \mathrm{s}$;

- wind air density $\rho, \mathrm{kg} / \mathrm{m}^{3}$, depending on the current values of atmospheric pressure $p_{a}, \mathrm{MPa}$, and air temperature $T_{a}, K$, in accordance with Clapeyron equation $[8,13]$;

- power consumption $W_{\text {cons }}, \mathrm{kW} \cdot \mathrm{h}$, including consumers' electric and heat capacity (parameter $\left.G_{m}\right)$.

Control action assignment for frequency converter or intensifier should change by analytic regression algorithms of the view:

$$
U_{c}=f\left(V, p_{a}, T_{a}, G_{m}\right) \text {. }
$$

For the function (1) realization it is necessary to use the base of meteorological data for the area of the supposed WP location and to process them statistically by experimental design methods. The required multi-parametric dependences are received in the form of nonlinear and linearized regression models with the use of matrix methods of the least squares.

The mathematical models of the WP control algorithm PCH-SG for the operation in the optimum area are received on the basis of the operation parameters data or experimental data of a prototype. For this purpose in (1) we obtained the parameters " $a_{j}$ " of the linearized four-factors model of the view

$$
U_{c}=a_{1} V+a_{2} p_{a}+a_{3} T_{a}+a_{4} G_{m}+\zeta,
$$

where $\zeta$-disturbance matrix (of unaccounted factors). 
As a result of calculations by the model (2) for the WP of "Briz-5000" type located at coast of Ladoga lake, the 4-factorial equation of linearized regression is received:

$$
\begin{aligned}
& U_{c}=12.214 V+0.219 p_{a}+0.92 T_{a}- \\
& -0.022 G_{m}+9.602,
\end{aligned}
$$

which is the desired algorithm of the invariant task and control of the WP electromechanical system. As it is seen from the expression (3), the factors $V(12.214)$ and $T_{a}(0.92)$ have got the largest influence. Therefore, in the non-expert systems it is possible to calculate the given wind parameters alone.

The covariance analysis of the received dependency (3) has shown [13] that these regression algorithms to the full extent trace the current input disturbances and correct the maximum of electric power generation.

The automatic stabilization of the WP output pres- sure is provided in the system of invariant control SGPCH (Fig. 2) which contains: external perturbation actions sensors; block of calculation of the optimum speed of SG shaft; pressure PI-controller at WP outlet; $\mathrm{PCH}-\mathrm{SG}$ generating system with the control law $U / f^{2}=$ const, output voltage sensor, WP mechanic part.

The basic lack of the given scheme is the necessity to install a step-by-step controlled intensifier which automatically adjusts the SG rotational frequency to the reading of maximum capacity according to characteristics. Therefore, at output voltage stabilization availability by means of consumers' automatic unloading, ballast loading or an internal contour of SG stabilization, it is possible to apply structure with an output current control loop (Fig. 3). A number of patents for the utility models $[5,6,22]$ has been received for these WP structures.

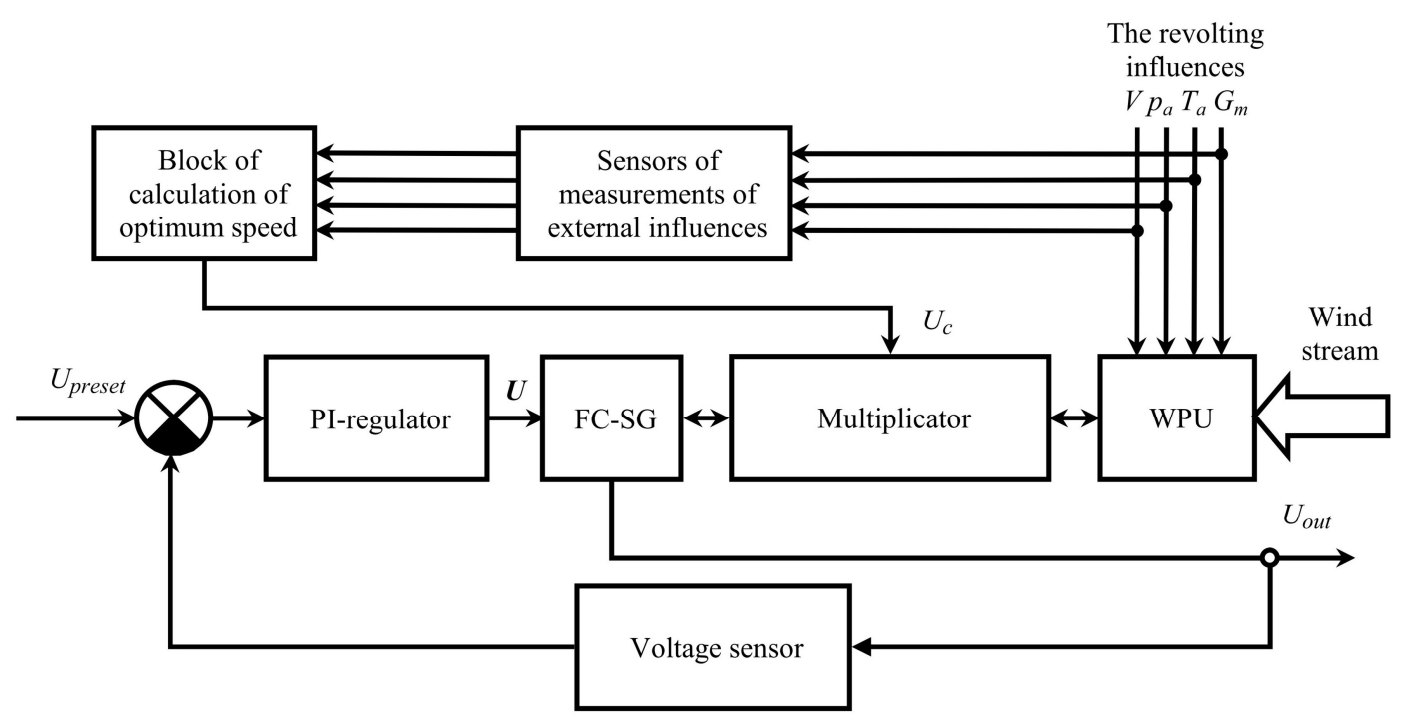

Fig. 2. Structure of combined ACS of local WP: $U_{\text {preset }}$ - preset voltage signal; $U$ - preset wind flow optimization influence; $U_{c}-$ frequency converter control action, $U_{\text {out }}-$ WP output voltage

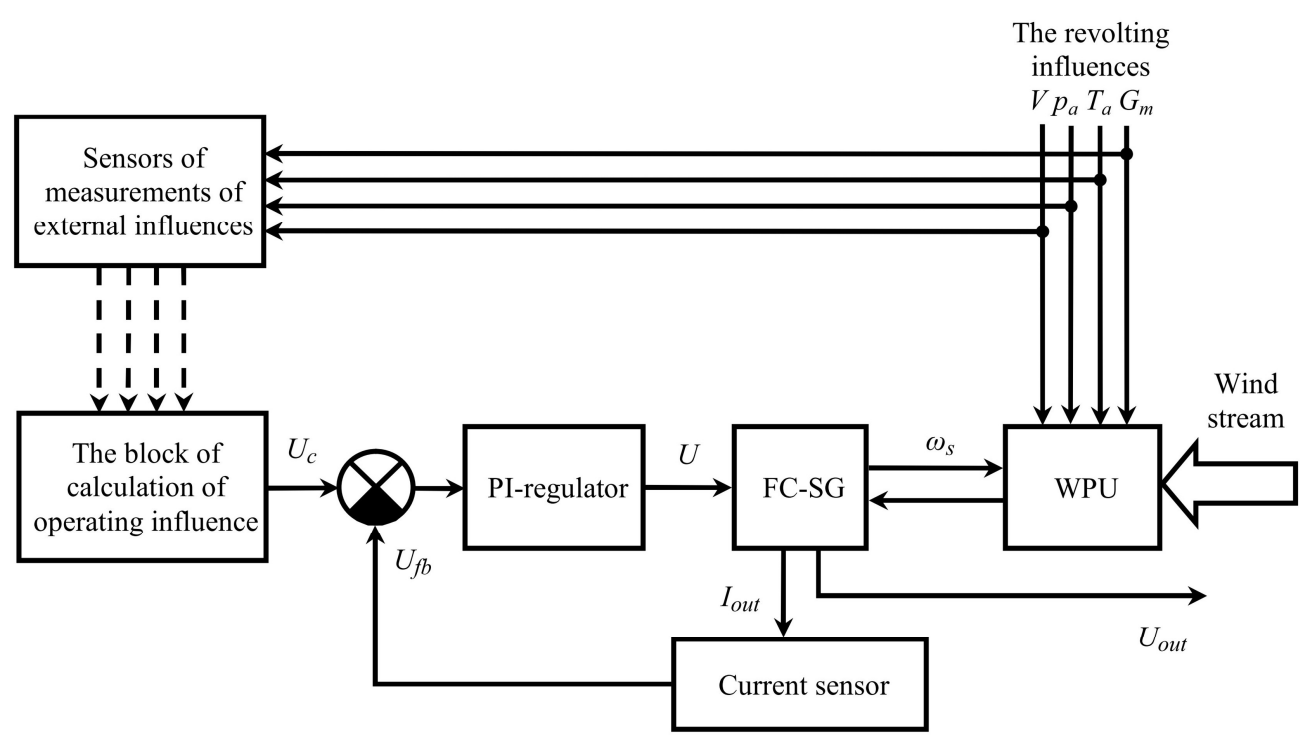

Fig. 3. Structure of combined ACS of local WP: $U_{f b}$ - feedback signal on output current $I_{\text {out }}$ (capacity), $\omega_{s}-$ windwheel shaft speed; $U_{\text {out }}-$ WP output voltage 


\section{Электромеханические системы}

\section{Linquistic approach in power generation} predicting

The wind flow power fluctuations lead to significant fluctuations of generated electric power, and at the regions where there is a constant wind flow, the WP power won't comply with load schedule even at the optimized wind cadaster [13].

As the linguistic variable of wind speed can be represented by the ordered term-set of fuzzy variables, the linguistic approach allows one to describe the decision problem elements of electric power generation adequately. The approximate estimations expressed by means of fuzzy concepts formalize fuzzy descriptions by means of fuzzy sets in the conditions of uncertainty of the energy carrier. At the comparison of the developed WP power with the load schedule it is possible to justify electric power accumulation.

In this case the WP application enables to save diesel fuel. It is obvious that in calm a diesel unit capacity is determined by the schedule of electric loading, and in case of the wind plant operation, the energy lack is made up with the diesel station while the quantity of spent energy (hydrocarbonic fuel) can be analyzed using power coverage belonging.

The problem of effective energy accumulation generated by the WP via wind use is one of the significant and the most challenging problems of the WP. The choice of type and capacity of the accumulating device refers to the field of the optimization of power supply reliability by backing up.

The ability to operate fuzzy initial data can be referred to the features of a linguistic approach [22-26], and, within this non-traditional method, there is a possibility to correctly consider such kinds of uncertainties as variability of wind.

It is possible to state that such method is flexible enough, and in case of its application, it is possible to consider the opinions of experts at drawing up the ownership of the fuzzy Beaufort scale.

In case the area corresponds to a relatively even wind speed variation, and deviation of a random variable from the expected value is low enough, the adjustment of the fuzzy scale with the reduction of the basis of fuzzy triangle membership functions (Fig. 4) is possible.

The pulsations of speed and air flow energy are caused by a general character of wind structure forming, local features, in particular, by specific landscape and relief. The simplicity and vizualization of the offered approach for coordination of the generated and consumed power on the basis of a short-term forecasting of mode management also provides the premise for the invention of adaptive fuzzy control.

\section{Simulations results}

The undertaken study of a principal possibility of using a predictive algorithm of fuzzy control in the tasks of power distribution in an autonomous electrical supply system with a WP has been received on the basis of the simulation model designed by means of applied MATLAB Simulink programs (Fig. 4b).

A fuzzy controller works under the Mamdani algorithm control [25-31]. The algorithm adjustment is made automatically proceeding from the system parameters by four input linguistic variables and four output variables. Thus, the system of 33 rules of fuzzy control is made at various random values of wind flow.

As a result of modelling, it was found out that the fuzzy controller under Mamdani algorithm control adequately fulfils the objective functions assigned to it. In a real time mode the optimum values of output control actions depending on the wind speed and loading at the consumer are determined by the controller. Thus, the decision for each situation is determined in a short time in the "On-line" mode.

Therefore, it is possible to single out such advantages as the control system flexibility because, during a control procedure, the controller does not allow premature switchings ( 0.5 mark) caused by a sudden impact of this or that parameter.

In the course of the research it is stated that, at more irregular daily wind motion and schedule of electric loading, the quantity of switchings increases which, in its turn, worsens the switchgear technical condition. Therefore, the decrease of undesirable

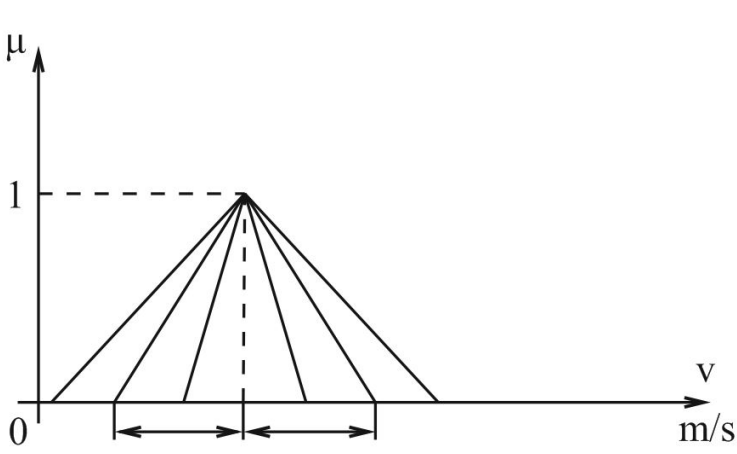

a)

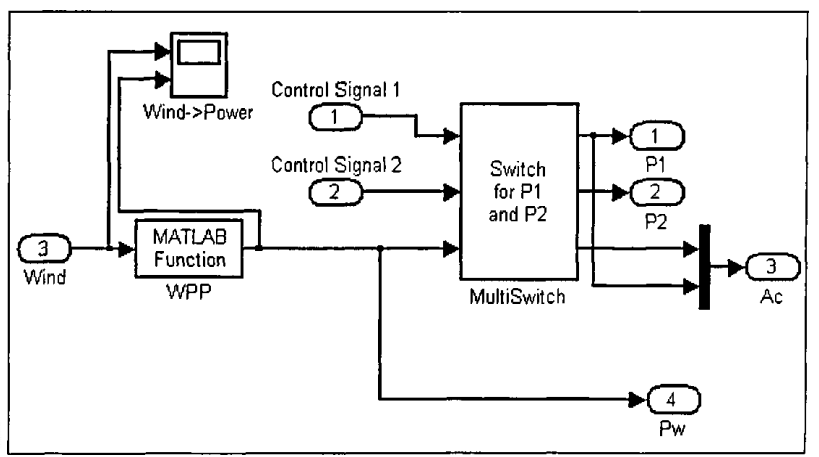

b)

Fig. 4. Linguistic variable of wind speed (a) and WP model (b) 
switchings in this case is urgent. Power distribution fuzzy control algorithms under the study are distinguished by the possibility of slight extension in case of the necessity in additional functional requirements. Under the change of the objective function of management or system elements it is enough to correct the rules of fuzzy control. The nature of fuzzy algorithms is that it allows one to produce such changes quickly and with adaptation to the WP new operating conditions. On the basis of the undertaken research it is possible to confirm that the suggested fuzzy algorithms are reasonably effective in terms of a computational procedure for predicting the amount of generated WP power at stochastic uncertainties of the input information and disturbances.

\section{Summary}

1. The analysis of the ARC PSS condition has demonstrated that a reliable and power efficient power supply of autonomous objects is an actual problem. As a result of the analysis of autonomous APS operation and WP structures, the technical requirements for the combined PSS were elaborated for power efficient electrical supply of remote objects.

2. The study of new structures of the autonomous PSS with invariant WP based on SG-PCH has shown their advantages over the traditional ones. It is established that the WP operation at optimum modes provides $30-50 \%$ increase of electric power generation.

3. Adequately, the WP model represents an object of experimental design theory with the invariant ACS providing electric power quality constraints. The models of self-contained generating complex elements are developed including WP, SG-PCH and PSS in the form of the equations of linear regressions tracing stochastic disturbances and providing maximum electric power generation.

4. Application of fuzzy logic instrument enables to adequately predict WP electric energy generation and hydrocarbon fuel consumption by traditional energy sources.

\section{References}

1. Puzhaylo A.F., etc. Energosberezheniye $i$ avtomatizatsiya elektrooborudovaniya kompressornykh stantsiy: monografiya [Energy-Saving Electrical Equipment and Automation of Compressor Stations: Monograph], Nizhny Novgorod, Vektor TiS, 2010, $560 \mathrm{p}$.

2. Puzhaylo A.F., etc. Energosberezheniye $i$ avtomatizatsiya elektrooborudovaniya kompressornykh stantsiy: monografiya [Energy-Saving Electrical Equipment and Automation of Compressor Stations: Monograph], Nizhny Novgorod, Vektor TiS, vol. 2, 2011. 664 p.

3. Kryukov O.V. [Experience of Creation of Energy-Efficient Electric Drives for Gas Pumping Units]. AEP-2014 [AEP 2014], Saransk, 2014, pp. 157-163. (in Russ.)
4. Babichev S.A., Zakharov P.A. Automated Monitoring System for Drive Motors of GasCompressor Units. Automation and Remote Control, 2011, vol. 72, no. 6, pp. 175-180. DOI: $10.1134 / \mathrm{S} 0005117911010176$

5. Babichev S.A., Titov V.G. Automated Safety System for Electric Driving Gas Pumping Units. Russian Electrical Engineering, 2010, vol. 81, no. 12, pp. 649-655. DOI: 10.3103/S1068371210120047

6. Babichev S.A., Bychkov E.V. Analysis of Technical Condition and Safety of Gas-Pumping Units. Russian Electrical Engineering, 2010, vol. 81, no. 9, pp. 489-494. DOI: 10.3103/S1068371210090075

7. Kryukov O.V. [Built-in Diagnostics and Forecasting of Work of Asynchronous Electric Drives]. Izvestiya VUZov. Elektromekhanika [Proceedings of the Universities . Electromechanics], 2005, no. 6, pp. 43-46. (in Russ.)

8. Milov V.R., Suslov B.A. Intellectual Management Decision Support in Gas Industry. Automation and Remote Control, 2011, vol. 72, no. 5, pp. 10951101. DOI: $10.1134 / \mathrm{S} 0005117911050183$

9. Titov V.V. [Development of Automation Autonomous Wind Energy Plant]. Avtomatizatsiya $v$ promyshlennosti [Automation Industry], 2009, no. 4, pp. 35-37. (in Russ.)

10. Stepanov S.E. [Increasing the Stability of the Electric Centrifugal Compressors at Compressor Stations of Gazprom, OJSC. Gazovaya promyshlennost [Gas industry], 2014, no. 8 (710), pp. 50-56. (in Russ.)

11. Kiyanov N.V., Pribytkov D.N., Gorbatushkov A.V. Concept for Development of Invariant Automated Electric Drives for Water Recycling Systems with Fan Cooling Towers. Russian Electrical Engineering, 2007, vol. 78, no. 11, pp. 621-627. DOI: 10.3103/S1068371207110120

12. Babichev S.A., Bychkov Ye.V. [Analysis of Technical State of Security Electrically Driven Gas Pumping Aggregates]. Elektrotekhnika [Electrical engineering], 2010, no. 9, pp. 30-36. (in Russ.)

13. Serebryakov A.V., Kryukov O.V. Intellektualnyye vetroenergeticheskiye ustanovki dlya avtonomnykh sistem elektrosnabzheniya [Intelligent Wind Turbines for Independent Power Supply Systems], Nizhniy Novgorod, NGTU im. R.Ye. Alekseyeva Publ., 2014. 120 p.

14. Serebryakov A.V., Titov V.G. [Forecasting Technical Condition of Wind Power Installations]. Elektrotekhnika [Electrical engineering], 2017, no. 1, pp. 60-65. (in Russ.)

15. Gorbatushkov A.V., Stepanov S.Ye. [Principles of Construction of Electric Power Facilities Invariant]. Avtomatizirovannyy elektroprivod i promyshlennaya elektronika [Automatic Electric and Industrial Electronics], 2010, pp. 38-45. (in Russ.)

16. Stepanov S.E. [Ways of Modernization of Electrically Driven Gas Pumping Units]. Yelektromekhanichni i yenergozberigayuchi sistemi [Electro- 


\section{Электромеханические системы}

mechanical and Energy Systems], 2012, no. 3(19), pp. 209-212. (in Ukraine)

17. Vasenin A.B., Titov V.G. [How to Increase Efficiency of Wind Power Installations], Glavnyi energetic [Chief Power Engineer], 2015, no. 1, pp. 58-64. (in Russ.)

18. Vasenin A.B. [Experimental Stand Electromechanical Parts of the Wind Power Installation]. Privodnaya tekhnika [Drive Technology], 2012, no. 4, pp. 2-11. (in Russ.)

19. Vasenin A.B. [Functionality of the Wind Power Installations when Powered Remote Objects]. Elektrooborudovanie: ekspluatatsiya i remont [Electrical equipment: maintenance and repair], 2014, no. 2, pp. 50-56. (in Russ.)

20. Serebryakov A.V. [Monitoring of an Electromechanical Part of Wind Power Installation]. Glavnyi energetic [Chief Power Engineer], 2013, no. 2, pp. 32-37. (in Russ.)

21. Vasenin A.B. [Design of Electromechanical and Control Systems of the Wind Power Weary Consumers Wok Gas Transmission]. Izvestiya of the Tula State University. Technical science, 2011, no. 5(1), pp. 47-51. (in Russ.)

22. Steklov A.S., Titov V.G. [Development of Model of Expert System of Diagnostics and Forecasting of Technical Condition of Electrical Power Systems]. Elektrotehnika: setevoi elektronnyi nauchnyi zhurnal [Russian Internet Journal of Electrical Engineering], 2016, vol. 3, no. 2, pp. 24-27. (in Russ.)

23. Stepanov S.Ye., Titov V.G. [Embedded Systems for Monitoring the Technical Condition of Electric Energy Security for Transport of Gas]. Energobezopasnost $i$ energosberezheniye [Energy Security and Energy Efficiency], 2012, no. 2, pp. 5-10. (in Russ.)

24. Vasenin A.B. [Fuzzy Models and Wind Power Plants Control Algorithms]. Upravleniye $v$ tekhnicheskikh, ergaticheskikh, organizatsionnykh $i$ setevykh sistemakh [Management in Technical,
Ergatic, Organizational and Network Systems], 2012, pp. 467-469. (in Russ.)

25. Papkov B.V. Reliability of Functioning of Reserved Power Generation Facilities of the Gas Industry]. Gazovaya promyshlennost' [Gas Industry], 2016, no. 4 (736), pp. 96-100. (in Russ.)

26. Steklov A.S., Titov V.G. [Neuro and Indistinct Model of Diagnosing of Technical Condition of Synchronous Generator]. Elektrooborudovanie: ekspluatatsiya I remont [Electrical Equipment: Operation and Repair], 2016, no. 1, pp. 26-33. (in Russ.)

27. Titov V.G., Chernov Eu.A., Shahov A.V. [Differentiation of Loading in Systems of Power Supply of Independent Consumers]. Trudy NGTU imeni R.Eu. Alekseeva [Transactions of NNSTU n.a. R.E. Alexeyev], 2015, no. 2 (109). pp. 203-209. (in Russ.)

28. Vasenin A.B. [Control Algorithms of Electromechanical Systems of the Main Transport of Gas]. Proceedings of VIII International conference AED2014 in 2 vol. Editor-in-chief Gulyaev I.V. Saransk, 2014, pp. 404-409.

29. Steklov A.S., Titov V.G. [Definition of Degree of Operability of the Synchronous Generator with Application of Artificial Neuro and Indistinct Networks]. Vestnik Chuvashskogo universiteta [Bulletin of Chuvash University], 2016, no. 1, pp. 97-104. (in Russ.)

30. Steklov A.S., Titov V.G. [System of Diagnostics of Technical Condition of Synchronous Generator]. Trudy NGTU imeni R.Eu. Alekseeva [Transactions of NNSTU n.a. R.E. Alexeyev], 2016, no. 1, pp. 60-64. (in Russ.)

31. Kadin S.N., Kazachenko A.P., Reunov A.V. Issues Related to Development of Metrological Assurance in Design of Gazprom Facilities. Measurement Techniques, 2011, vol. 54, no. 8, pp. 944-952. DOI: $10.1007 / \mathrm{s} 11018-011-9832-7$

Received 2 May 2017 


\title{
ЭНЕРГОЭФФЕКТИВНЫЕ СИСТЕМЫ ЭЛЕКТРОСНАБЖЕНИЯ ЭЛЕКТРОПРИВОДОВ НЕФТЕГАЗОПРОВОДОВ
}

\author{
О.В. Крюков ${ }^{1}$, А.В. Серебряков ${ }^{2}$ \\ ${ }^{1}$ АО «Гипрогазцентр», г. Нижний Новгород, Россия, \\ ${ }^{2}$ Нижегородский государственный технический университет им. Р.Е. Алексеева, \\ г. Нижний Новгород, Россия
}

Рассмотрено современное состояние развития автономных систем электроснабжения, включая объекты газотранспортных систем. Обосновано использование в комбинированных генераторных комплексах альтернативных источников электроэнергии на базе ветроэнергетических установок. Предложены варианты структур электросетей для питания вдольтрассовых потребителей с использованием ветроэнергетических установок. Проанализированы энергоэффективные инвариантные системы на базе комбинированных установок по схеме «синхронный генератор - преобразователь частоты». Получены прогнозируемые объемы выработки электроэнергии энергоисточниками при стохастическом характере ветрового потока. Приведен ряд примеров внедрения новых комбинированных систем автономного электроснабжения с использованием возобновляемых энергоисточников на магистральных газопроводах РФ.

Ключевые слова: ветроэнергетическая установка, инвариантная система, энергоэффективность, синхронный генератор, преобразователь частоты.

\section{Лumepamypa}

1. Пужайло, А.Ф. Энергосбережение и автоматизация электрооборудования компрессорных станичий: моногр. / А.Ф. Пужайло и др. - Н. Новгород: Вектор ТиС, 2010. - 560 с.

2. Пужайло, А.Ф. Энергосбережение и автоматизация электрооборудования компрессорных станичии: моног. / А.Ф. Пужайло и др. - Н. Новгород: Вектор ТиС, 2011. - T. 2. - 664 с.

3. Крюков, О.В. Опьт создания энергоэффективных электроприводов газоперекачивающих агрегатов / О.В. Крюков // В сборнике: Трудь VIII Международной (ХІХ Всероссийской) конференции по автоматизированному электроприводу АЭП-2014: в 2 m. - Саранск, 2014. - C. 157-163.

4. Babichev, S.A. Automated monitoring system for drive motors of gas-compressor units / S.A. Babichev, P.A. Zakharov // Automation and Remote Control. - 2011. - Vol. 72, no. 6. - P. 175-180. DOI: 10.1134/S0005117911010176

5. Babichev, S.A. Automated safety system for electric driving gas pumping units / S.A. Babichev, V.G. Titov // Russian Electrical Engineering. - 2010. - Vol. 81, no. 12. - P. 649-655. DOI: 10.3103/S1068371210120047

6. Babichev, S.A. Analysis of technical condition and safety of gas-pumping units / S.A. Babichev, E.V. Bychkov // Russian Electrical Engineering. - 2010. - Vol. 81. - C. 489-494. DOI: 10.3103/S1068371210090075

7. Крюков, О.В. Встроенная система диагностирования и прогнозирования работы асинхронных электроприводов // Известия вузов. Электромеханика. - 2005. - № 6. - C. 43-46.

8. Milov, V.R. Intellectual management decision support in gas industry / V.R. Milov, B.A. Suslov // Automation and Remote Control. - 2011. - Vol. 72, no. 5.- C. 1095-1101. DOI: 10.1134/S0005117911050183

9. Титов, В.В. Разработка АСУ автономными ветроэнергетическими установками / В.В. Титов // Автоматизация в промышленности. - 2009. - № 4. - Р. 35-37.

10. Степанов, С.Е. Повышение устойчивости работы электроприводов иентробежных нагнетателей на компрессорных станщиях ОАО «Газпром» / С.Е. Степанов // Газовая промышленность. - 2014. № 8 (710). - C. 50-56.

11. Kiyanov, N.V. A Concept for the development of invariant automated electric drives for the water recycling systems with fan cooling towers Russian Electrical Engineering / N.V. Kiyanov, D.N. Pribytkov, A.V. Gorbatushkov. - 2007. - Vol. 78, no. 11. - P. 621-627. DOI: 10.3103/S1068371207110120

12. Бабичев, С.А. Анализ технического состояния и безопасности электро-приводных газоперекачивающих агрегатов / С.А. Бабичев, Е.В. Бычков // Электротехника. - 2010. - № 9. - С. 30-36.

13. Серебряков, А.В. Интеллектуальные ветроэнергетические установки для автономных систем электроснабжения / А.В. Серебряков, О.В. Крюков. - Нижний Новгород: НГТУ им. Р.Е. Алексеева, 2014. - 120 с.

14. Серебряков, А.В. Прогнозирование технического состояния ветроэнергетических установок / А.В. Серебряков, В.Г. Титов // Электротехника. - 2017. - № 1. - С. 60-65.

15. Горбатушков, А.В. Приниипь построения инвариантных электроприводов энергетических объектов / А.В. Горбатушков, С.Е. Степанов // Автоматизированный электропривод и промышленная электроника. Труды IV ВНПК / под общ. ред. В.Ю. Островлянчика. - Новокузнеик, 2010. - С. $38-45$. 


\section{Электромеханические системы}

16. Степанов, С.Е. Пути модернизации электроприводных газоперекачивающих агрегатов / С.Е. Степанов // Електромеханічні І енергозберігаючі системи. - 2012. - № 3 (19). - С. $209-212$.

17. Васенин, А.Б. Как повысить эффективность ветроэнергетических установок / А.Б. Васенин, В.Г. Титов // Главный энергетик. - 2015. - № 1. - С. 58-64.

18. Васенин, А.Б. Экспериментальный стенд электромеханической части ветроэнергетической установки // Приводная техника. - 2012. - № 4. - C. 2-11.

19. Васенин, А.Б. Функичиональные возможности ветроэнергетических установок при питании удаленных объектов / А.Б. Васенин // Электрооборудование: эксплуатация и ремонт. - 2014. - № 2. - С. 50-56.

20. Серебряков, А.В. Мониторинг электромеханической части ветроэнергетических установок / A.В. Серебряков // Главньй энергетик. - 2013. - № 2. - С. 32-37.

21. Васенин, А.Б. Проектирование электромеханической части и систем управления ветроэнергетических установок газотранспортных потребителей / А.Б. Васенин // Известия Тульского государственного университета. Технические науки. - 2011. - № 5-1. - С. 47-51.

22. Стеклов, А.С. Разработка модели экспертной системы диагностики и прогнозирования технического состояния электроэнергетических систем / А.С. Стеклов, В.Г. Титов // Электротехника: сетевой электронный научный журнал. - 2016. - T. 3, № 2. - С. 24-27.

23. Степанов, С.Е. Встроенные системы мониторинга технического состояния электроприводов для энергетической безопасности транспорта газа / С.Е. Степанов, В.Г. Титов // Энергобезопасность и энергосбережение. - 2012. - № 2. - С. 5-10.

24. Васенин, А.Б. Нечеткие модели и алгоритмы управления ветроэнергетическими установками / А.Б. Васенин // В сборнике: Материаль конференции «Управление в технических, эргатических, организаичонных и сетевых системах» / под ред. С.Н. Васильева и др. - 2012. - C. 467-469.

25. Папков, Б.В. Надежность функционирования резервируемых объектов электроэнергетики газовой промышленности / Б.В. Папков // Газовая промышленность. - 2016. - № 4 (736). - С. 96-100.

26. Стеклов, А.С. Нейро-нечеткая модель диагностирования технического состояния синхронного генератора / А.С. Стеклов , В.Г. Титов // Электрооборудование: эксплуатация и ремонт. - 2016. - № 1. C. 26-33.

27. Титов, В.Г. Дифференцирование нагрузки в системах электроснабжения автономных потребителей / В.Г. Титов , Е.А. Чернов, А.В. Шахов // Труды НГТУ им. Р.Е. Алексеева. 2015. № 2 (109). C. 203-209.

28. Васенин, А.Б. Алгоритмы управления электромеханическими системами магистрального транспорта газа // Труды VIII Международной конференциии АЭП-2014: сб.: в 2 m. / отв. ред. И.В. Гуляев. - Саранск, 2014. - C. 404-409.

29. Стеклов, А.С. Определение степени работоспособности синхронного генератора с применением искусственных нейро-нечетких сетей / А.С. Стеклов , В.Г. Титов // Вестник Чувашского университета. 2016. - № 1. - C. 97-104.

30. Стеклов, А.С. Система диагностики технического состояния синхронного генератора / А.С. Стеклов, В.Г. Титов // Труды НГТУ им. Р.Е. Алексеева. - 2016. - № 1. - С. 60-64.

31. Kadin, S.N. Questions related to the development of metrological assurance in the design of Gazprom facilities / S.N. Kadin, A.P. Kazachenko, A.V. Reunov // Measurement Techniques. - 2011. - Vol. 54, no. 8. P. 944-952. DOI: 10.1007/s11018-011-9832-7

Поступила в редакцию 2 мая 2017 2.

Крюков Олег Викторович, д-р техн. наук, доцент, главный специалист, АО «Гипрогазцентр», г. Нижний Новгород, o.kryukov@ggc.nnov.ru.

Серебряков Артем Владимирович, канд. техн. наук, доцент, Нижегородский государственный технический университет им. Р.Е. Алексеева, г. Нижний Новгород.

\section{ОБРАЗЕЦ ЦИТИРОВАНИЯ}

Крюков, О.В. Энергоэффективные системы электроснабжения электроприводов нефтегазопроводов / О.В. Крюков, А.В. Серебряков // Вестник ЮУрГУ. Серия «Энергетика». - 2017. - Т. 17, № 3. - С. 102-110. DOI: $10.14529 /$ power170312

\section{FOR CITATION}

Kryukov O.V., Serebryakov A.V. Energy Efficient Power Supply Systems of Oil and Gas Pipelines Electric Drives. Bulletin of the South Ural State University. Ser. Power Engineering, 2017, vol. 17, no. 3, pp. 102-110. DOI: $10.14529 /$ power 170312 